Case Report

\title{
Thyroid tissue as a submandibular mass: a case report
}

\author{
Faramarz Babazade ${ }^{1)}$, Hamed Mortazavi ${ }^{2)}$, Hamed Jalalian ${ }^{1)}$ and Ehsan Shahvali ${ }^{3)}$ \\ ${ }^{1)}$ Department of Oral and Maxillofacial Surgery, Mashhad Dental Faculty, Mashhad, Iran \\ ${ }^{2)}$ Department of Oral Medicine, Hamadan Dental Faculty, Hamadan, Iran \\ ${ }^{3)}$ Department of Orthodontics, Hamadan Dental Faculty, Hamadan, Iran
}

(Received 2 June and accepted 24 September 2009)

\begin{abstract}
Ectopic thyroid gland is a rare phenomenon that appears most frequently in the cervical midline and very rarely in other sites such as the submandibular region. This article reports a painless, non-tender and firm thyroid tissue mass in the right submandibular region of a 29-year-old female patient. Physicians should consider ectopic thyroid tissue as a differential diagnosis of submandibular swellings and be aware that this ectopic gland is the only functional thyroid tissue in $70 \%$ of cases. (J Oral Sci $51,655-657,2009$ )
\end{abstract}

Keywords: ectopic; thyroid gland; submandibular space.

\section{Introduction}

During the third to fourth week of gestation, the thyroid gland develops as an epithelial proliferation from the median plate of the floor of the pharyngeal gut $(1,2)$. In approximately the seventh week of foetal life, the thyroid gland descends from the foramen caecum (located between the posterior third and anterior two thirds of the tongue) to its final location anterior to the pretrachea and larynx $(3,4)$. Therefore, discrepancy in the descent of the thyroid gland may lead to ectopic thyroid tissue between the first and last positions of this gland $(1,4)$. About $90 \%$ of all ectopic thyroid tissues are found in these regions, whereas about $10 \%$ have been reported in other anatomical locations

Correspondence to Dr. Hamed Mortazavi, Department of Oral Medicine, Hamadan Dental Faculty, Fahmideh Blv., Post Code: 65176-59114, Hamadan, Iran

Tel: +98-9155147386

Fax: +98-8118354220

E-mail: Mortazavi@umsha.ac.ir including the lingual region (with clinical incidence between 1:3,000 and 1:10,000), infrahyoid, trachea, oesophagus, mediastinum and heart $(2,4)$. Dorsum of the tongue is the most frequent ectopic site of thyroid tissue, of which only $70 \%$ is functional (5). Another very rare ectopic location for thyroid tissue is the submandibular space (6,7). According to Zieren (2006), 18 similar cases of ectopic thyroid tissue have been reported in the submandibular space (6). Therefore, physicians should consider the possibility that a submandibular swelling could be an ectopic thyroid gland which can not be clinically distinguished from other swellings involving the submandibular area, such as salivary gland tumours or cysts.

\section{Case Report}

A 29-year-old woman with a history of right-sided asymptomatic swelling and primary diagnosis of a benign submandibular gland tumour was referred to the Maxillofacial Surgery Clinic at the Mashhad Dental University. The patient reported that although she had experienced difficulty in swallowing food about 8 years prior to her visit, the swelling had developed only in the previous 4 months. Her medical history showed iron deficiency anaemia and she was under medication with ferrous sulphate and acid folic. Oral examination revealed a nodular, non-tender, immovable pink mass with a smooth surface located in the floor of the mouth on the right side. The mass was $3 \times 4$ $\mathrm{cm}$ in size and was found to be firm with intact mucosa. Examination of the neck revealed a palpable, firm and asymptomatic mass $1.5 \times 2 \mathrm{~cm}$ in size near the submandibular region. On physical examination, the patient's blood pressure was 140/80 $\mathrm{mm} \mathrm{Hg}$ and her pulse was 70 beats per minute. A computed tomography (CT) scan taken to determine the precise position of the mass revealed an approximately $3 \times 4 \mathrm{~cm}$ calcified mass without extension 
to the bone (Fig. 1). Also, ultrasonic examination in this patient showed a well-defined mass in the submandibular region. After clinical and paraclinical assessments and based on provisional diagnosis of a neoplasm of the submandibular gland, the patient was subjected to resection of the mass under general anaesthesia with an extra-oral incision. The submandibular mass was excised and the resected tissue revealed two well-defined, solid, elastic and black-brown-coloured masses $37 \times 27 \times 32 \mathrm{~mm}$ and $10 \times$ $12 \times 15 \mathrm{~mm}$ in size. Histological examination showed thyroid follicles, colloid and fibrovascular capsule (Fig. 2). Three weeks after surgery, the functional parameters (T3, T4, T3 resin uptake, TSH) of thyroid were within the normal levels a CT scan taken 5 months after surgery appeared normal.

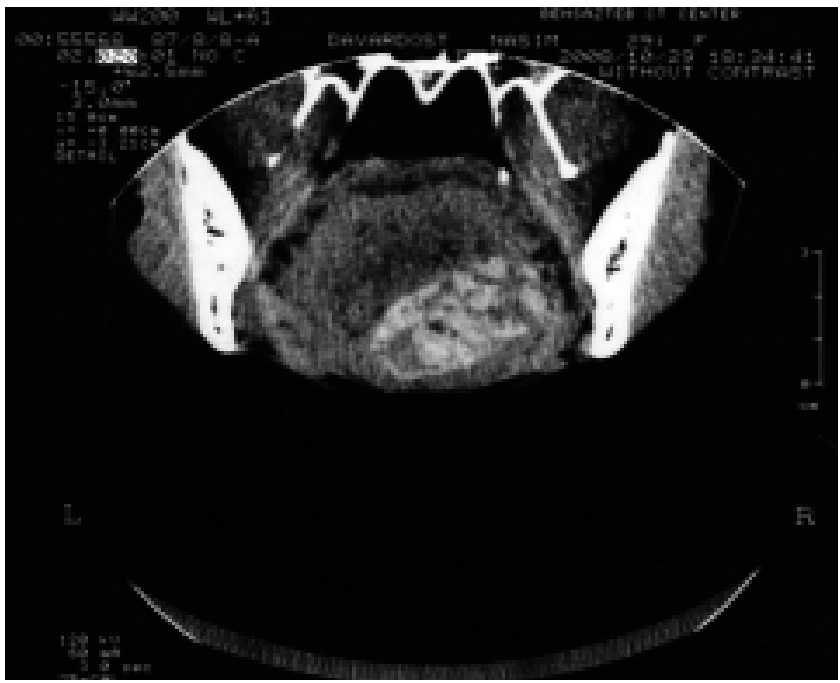

Fig. 1 A CT scan image in the coronal section showing a calcified mass in the right floor of the mouth without extension into the bone.

\section{Discussion}

Ectopic thyroid gland is a rare phenomenon that may be found in any position along the thyroglossal track. The most frequent (90\% of cases) position is the cervical midline; more rarely (10\% of cases), it appears in other anatomical regions $(1,4,6)$. After Hickman's report about ectopic thyroid tissue as a lingual thyroid, Zieren and Aköz demonstrated some cases in different locations $(6,8)$. One of the very rare locations for ectopic thyroid tissue as a mass is the submandibular region (7). Some reported cases of this lesion are listed in Table 1 (4,6-14). From the data in this table and results of the present study, ectopic thyroid tissue as a submandibular mass is most common in females and may present in any age. This can be explained in three ways: 1) displacement during the period

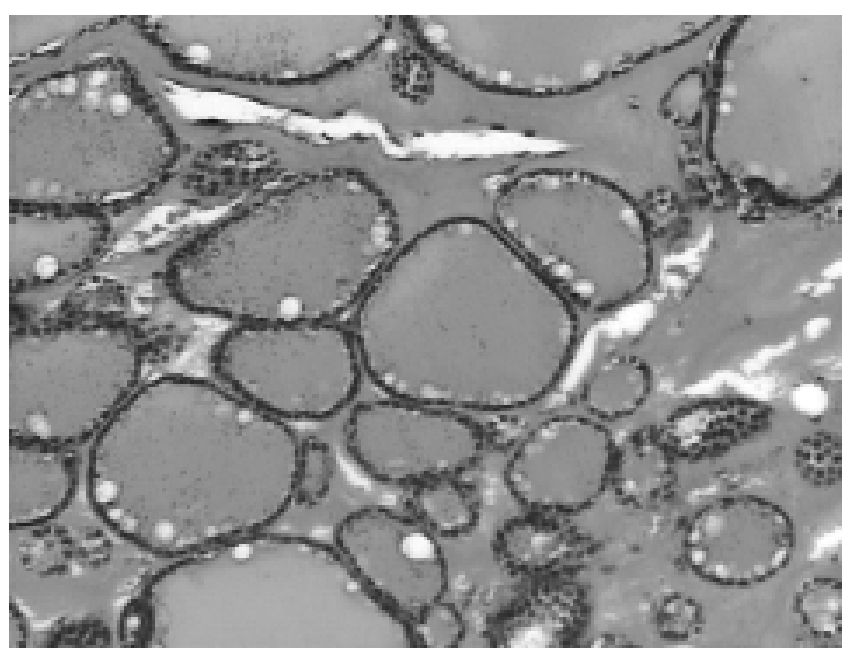

Fig. 2 Microscopic examination showing large and small ectopic thyroid follicles with colloid (H-E staining $\times 200)$.

Table 1 List of reports on submandibular thyroid tissue

\begin{tabular}{lcccc}
\hline Author(s) & Reported year & Age of patient (s) & Sex & Location or site \\
\hline Zieren et al. (6) & 2006 & 81 & $\mathrm{~F}$ & Sub-mand \\
Kanaya et al. (7) & 2005 & 53 & $\mathrm{~F}$ & Sub-mand \\
Feller et al. (4) & 2000 & 75 & $\mathrm{~F}$ & Sub-mand \\
Gin et al. (9) & 1998 & 29 & $\mathrm{~F}$ & Sub-mand \\
Aköz et al. (8) & 1998 & 66 & $\mathrm{M}$ & Sub-mand \\
$\begin{array}{l}\text { DiBenedetto } \\
(10)\end{array}$ & 1997 & 4 & $\mathrm{M}$ & Sub-mand \\
$\begin{array}{l}\text { Sambola-Cabrer } \\
\text { et al. (11) }\end{array}$ & 1996 & 34 & & \\
$\begin{array}{l}\text { Sironi et al. (12) } \\
\text { Morgan et al. }\end{array}$ & 1996 & & & Sub-mand \\
$(13)$ & 1995 & 45 & $\mathrm{~F}$ & Sub-mand \\
Helidonis et al. & 1980 & 50 & $\mathrm{~F}$ & Sub-mand \\
$(14)$ & & 30 & & \\
\hline
\end{tabular}

F, female; M, male; Sub-mand, Submandibular region 
of embryonic development; 2) implantation of tissue during surgical procedures on a normally located thyroid gland; and 3) metastasis of thyroid carcinoma (4). The management of ectopic thyroid tissue depends on some factors such as size of the mass, local symptoms, the patient's age, state of the thyroid gland and related complications (e.g., ulceration, hemorrhage, malignancy) $(5,15)$. The accepted treatment plan in patients with clinical signs such as dysphagia and airway obstruction is surgical removal of the ectopic mass $(4,16)$. Prior to surgical removal, thyroid function tests and thyroid scan must be performed to decrease the risk of iatrogenic hypothyroidism $(2,4,7)$ because in $70 \%$ of cases this ectopic gland is the only functional thyroid tissue (1).

In conclusion, physicians should consider the possibility that ectopic thyroid gland could be a differential diagnosis of submandibular swelling. Awareness of the existence of normal and functional thyroid gland before surgical removal of ectopic thyroid tissue is essential $(4,6)$.

\section{References}

1. Neville BW, Damm DD, Allen CM, Bouquot JE (2002) Oral and maxillofacial pathology. 2nd ed, Saunders Elsevier, Philalelphia, 1-25.

2. Gallo A, Leonetti F, Torri E, Manciocco V, Simonelli M, De Vincentiis M (2001) Ectopic lingual thyroid as unusual cause of severe dysphagia. Dysphagia 16, 220-223.

3. Regezi JA, Sciubba JJ, Jordan RC (2008) Oral pathology: clinical pathologic correlations. 5th ed, Saunders Elsevier, St Louis, 237-261.

4. Feller KU, Mavros A, Gaertner HJ (2000) Ectopic submandibular thyroid tissue with a coexisting active and normally located thyroid gland: case report and review of literature. Oral Surg Oral Med Oral Pathol Oral Radiol Endod 90, 618-623.

5. Williams JD, Sclafani AP, Slupchinskij O, Douge C (1996) Evaluation and management of the lingual thyroid gland. Ann Otol Rhinol Laryngol 105, 312316.

6. Zieren J, Paul M, Scharfenberg M, Menenakos C
(2006) Submandibular ectopic thyroid gland. J Craniofac Surg 17, 1194-1198.

7. Kanaya H, Tanigaito Y, Shyono N, Hirabayashi H, Baba K (2005) A rare case of ectopic, normally functioning thyroid tissue presenting as a left submandibular mass. Nippon Jibiinkoka Gakkai Kaiho 108, 850-853. (in Japanese)

8. Aköz T, Erdogan B, Ayhan M, Cinar F (1998) Ectopic submandibular thyroid Tissue. Rev Laryngol Otol Rhinol 119, 323-325.

9. Gin D, Gultekin SH, Ward RF, Hunley JR, Hoda SA (1998) Clear-cell follicular adenoma of ectopic thyroid in the submandibular region. Endocr Pathol 9, 339-346.

10. Di Benedetto V (1997) Ectopic thyroid gland in the submandibular region simulating a thyroglossal duct cyst: a case report. J Pediatr Surg 32, 1745-1746.

11. Sambola-Cabrer I, Fernández-Real JM, Ricart W, Barbas JF, Ollé M, Teruel J (1996) Ectopic thyroid tissue presenting as a submandibular mass. Head Neck 18, 87-90.

12. Sironi M, Assi A, Andruccioli M, Spreafico G (1996) Submandibular ectopic thyroid gland. Clin Nucl Med 21, 585. (Abstract)

13. Morgan NJ, Emberton P, Barton RP (1995) The importance of thyroid scanning in neck lumps - a case report of ectopic tissue in the right submandibular region. J Laryngol Otol 109, 674676.

14. Helidonis E, Dokianakis G, Papazoglou G, Pantazopoulos P, Thomopoulou H (1980) Ectopic thyroid gland in the submandibular region. J Laryngol Otol 94, 219-224.

15. Paludetti G, Galli J, Almadori G, Ottaviani F, D'Alatri L, Maurizi M (1991) Ectopic lingual thyroid. Acta Otorhinolaryngol Ital 11, 117-133. (in Italian)

16. Maurice N, Makeieff M, Delol J, Bec P, Crampette L, Guerrier B (1995) Ectopic lingual thyroid. Apropos of 3 cases. Ann Otolaryngol Chir Cervicofac 112, 399-405. (in French) 